\title{
SOCIETY OF AN'TIQUARIES
}

OFFICERS :

President :

SIR FREDERIC KENYON, G.B.E., K.C.B., F.B.A.

Treasurer:

R. HOLLAND-MARTIN, C.B.

Secretary:
Director:

REGINALD A. SMITH, B.A.

Assistant Secretary :

A. W. CLAPHAM, C.B.E., F.B.A. H. S. KINGSFORD, M.A.

All communications on Editorial matters and books for review should be addressed to the Assistant Becretary, Bociety of Antiquaries, Burlington Honse, Tondon, W. 1.

\section{PUBLICA'TIONS}

Copies can be obtained from Mr. Bernard Quaritch, 11 Grafton Street, Now Bond street, w. 1 .

\section{ARCHAEOLOGIA.}

Vols. I-XXVII. (Stock sold off)

Vols. XXVIII-XXXIV, each Volume in two Parts. Price 15s. per Part.

Vols. XXXV-XLV, each Volume in two Parts. Price 21s. per Part. Vol. XLV, Part 2, out of print.

Vols. XLVI-XLVIII, each Volume in two Parts. Price 30s. per Part.

Vols. XLIX-LXXXIV. Price varies. Vols. LI, LIV, $\mathcal{Q}$, and LXXIVout of print.

General Index to the Archaeologia, Vols. I-L. Price 2 Gruineas.

Vols. I-V. (Stock sold off)

VETUSTA MONUMENTA.

Vol. VI. Early portion. (Out of print)

CHAIR OF ST. PETER. Three plates. Price 1s.6d.

ILLUMINATIONS IN IRISH MSS. Four plates. Price 48.

THE EVANGELIA QUATUOR OF LINDAU. Two plates. Price 4s. Vol. VII.

TOMB OF AN ARCHBISHOP AT CANTERBURY. Five plates. Price $15 s$.

ATCHIEVEMENTS OF EDWARD, PRINCE OF WALES, IN THE CATHEDRAL CHURCH OF CANTERBURY. Five plates. Price $15 s$. ROYAL CUP OF THE KINGS OF FRANCE AND ENGLAND. Four plates. Price 15s.

OBITUARY ROLL OF JOHN ISLIP, ABBOT OF WESTMINSTER, Erc. Ten plates. Price 218 .

An Index to the 4rh, 5th, and 6rh Volumes. Fol. Price 7s. 6d. 8vo. Price 2s. 6d. Titte-page and Index to Vol. VI. Price 2s. 6d.

\section{PROCEEDINGS.}

First Series, Vols. I, II, and IV. Price 10s. 6d. per Vol. Vol. III out of print. Second Series, Vols. I-XX. Price 10s.6d. per Volume; or the set of the first ten Volumes, $£ 2$ 12s. 6d. The current parts of Vols. XXI-XXIII and the complete Vols. XXIV-XXX may also be had at $6 s$. each. Vols. XXXI, XXXII, $£ 1$ 1s. General Inoex ro Vols. I-XX. Price $16 s$.

\section{REPORTS OF THE RESEARCH COMMITTEE.}

No. 1. Excavations at Wroxeter in 1912; by J. P. Bushe-Fox. Price 28. 6d. No. 2 .

No. 3.

No. 4.

No. 5.

No. 6.

No. 7.

No. 8.

No. 9.

No. 10 .

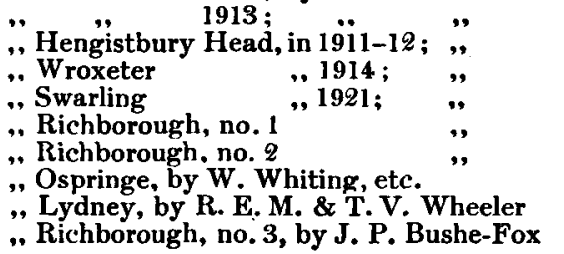

\begin{tabular}{|c|c|}
\hline \multicolumn{2}{|c|}{," } \\
\hline ", & " \\
\hline " & $"$ \\
\hline " & $" 6 d$ \\
\hline ", & $7 s .6 d$ \\
\hline & 5s." od. \\
\hline & $6 d$ \\
\hline
\end{tabular}


CODEX EXONIENSIS; a Collection of Anglo-Saxon Poetry. Edited by Benjamin Thonpe, F.S.A. 8vo. London, 1842. (Out of print)

LA3AMON's BRUT, or CHRONICLE of BRITAIN; a Poetical SemiSaxon Paraphrase of the Brut of Wace. Edited by $S_{\text {in Fremeric }}$ MaUnen, K.H. 3 vols. 8vo. 1847. (Out of print)

LIBER QUOTIDIANUS CONTRAROTULATORIS GARDEROBE ANNO 28 EDWARDI PRIMI. 4to. London, 1787. Price in cloth, $5 s$.

ORDINANCES FOR THE GOVERNMENT OF THE ROYAL HOUSEHOLD. 4to. London, 1790. (Out of print)

MAGNI ROTULI SCACCARII NORMANNIE. Edited by Thomas Stapteton, F.S.A. 2 vols. 8vo. London, 1840-4. Price in cloth, 10s. $6 d$.

ARCHAEOLOGICAL SURVEYS : Price 5s. each.

(1) KEN'S. By Georee Payne, F.S.A.

(2) HERTFORDSHIRE. By Sir John Evans, K.C.B., V.P.

(3) CUMBERLAND AND WESTMORLAND. By Chancerior Ferguson, F.S.A.; and LANCASHIRE NOR'TH-OF-THE-SANDS. By H. S. COWPER, F.S.A.

(4) LANCASHire. By William Harrigon.

(5) Herefordoshire. By Rev. J. O. Bevan, F.S.A., James Davies, and F. HaVerfiem, F.S.A.

(6) NORTHANTS. By T. J. George.

(7) OXFORdSHIRE. By P. Manning, F.S.A., and E. T. Leeds, F.S.A.

PRINTED BROADSIDES IN THE POSSESSION OF THE SOCIETY, by Robent Lemon, F.S.A. Price 10s. $6 d$.

ILLUSTRATED CATALOGUE OF THE EXHIBITION OF ENGLISH MEDIEVAL ALA BASTER IVORK. Price $15 s$.

RECENT INVESTIGATIONS RBGARDING THE FATE OF 'THE Princes IN THe TOWER. By L. E. Tanner, F.S. A., and Prof. W. Wright, F.S.A. Reprinted from Archaeologia, Vol. LXXXIV. 2s. $6 d$.

YARD AND METRE SCALE FOR PHOTOGRAPHIC PURPOSES. Price $6 d$. , or 5s. per dozen, post free.

\section{HISTORICAL PRINTS.}

1. Le Champ du Drap d'Or, or the Interview of Henry VIII and Francis I between Guines and Ardres, 1520. (Out of print)

2. Encampment of the English Forces near Portsmouth, 1545. £2 2s. 0d.

3. Embarkation of Henry VIII at Dover, 1520. f2 2s. 0d.

4. Procession of Edward VI from the Tower to Westminster. $£ 22 s .0 d$.

5. Departure of Henry VIII from Calais, 1544. $£ 11 s .0 d$.

6. Encampment of Henry VIII at Marquison, 1544. 10s. $6 d$.

7. Siege of Boulogne by Henry VIII, 1544. fl 11s. 6d.

8. Plan of London, temp. Elizabeth. (Out of print)

9. Roman pavement at Stunsfield, Oxon. (Out of print)

10. Two views of Mr. Lethieullier's Mummy. (Out of print)

11. Henry VII and his Queen; Henry VIII and Jane Seymour. El 1s. od.

12. Procession of Elizabeth to Blackfriars. $\pm 11 s, 0 d$.

13. Cenotaph of Lord Darnley, etc. £1 1s. 0 d.

14. Battle of Carberry Hill. \&1 1s. Od.

15. Three Children of Christian II, King of Denmark. \&1 18. $0 d$.

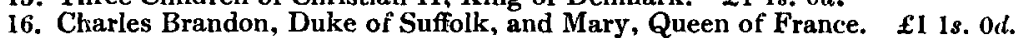

17. Frances, Duchess of Suffolk, and Adrian Stokes her second husband. fl 1s. od.

18. Lady Jane Grey. $£ 11$ s. $0 d$.

19. Edward VI granting the Palace of Bridewell for a Hospital. f1 1s. Od.

20. Charles I and Henrietta Maria. 11 1s. Od.

21. Plan of Whitehall. (Out of print)

22. View of the Charity Children in the Strand, 7 July 1713. 2 sheets. $f 11$ s. Od.

23. Portrait of Sir John Hawkwood. 10s. $6 d$.

24. Four Views of Stanton Harcourt, Oxon. £2 2s. $0 d$ 


\section{MEDIEVAL GHRISTIAN IMAGERY}

as illustrated by the painted windows of Great Malvern Priory

Church together with a description and explanation of all the ancient glass in the church

By G. MaN. RUSHFORTH

With nearly 200 illustrations. 63s. net

$\begin{array}{lllllllllllllllllllll}\mathbf{O} & \mathbf{X} & \mathbf{F} & \mathbf{O} & \mathbf{R} & \mathbf{D} & \mathbf{U} & \mathbf{N} & \mathbf{I} & \mathbf{V} & \mathbf{E} & \mathbf{R} & \mathbf{S} & \mathbf{I} & \mathbf{T} & \mathbf{Y} & \mathbf{P} & \mathbf{R} & \mathbf{E} & \mathbf{S} & \mathbf{S}\end{array}$

\section{PUBLICATIONS OF THE ROYAL ANTHROPOLOGICAL INSTITUTE}

52 UPPER BEDFORD PLACE, W.C. I

\section{Journal of the Royal Anthropological Institute}

IN HALF-YEARLY PARTS FIFTEEN SHILLINGS EACH

Vol. LXV, Part I, contains among other matter the following:

Africa: What do we know of it? Rev. E. W. Smitr.

The Canoe and the Bonito in Eddystone Island. A. M. Hocart, M.A.

Early Slavonic Pottery dug up at Kiselivka Hill, Kiev, in 1932. S. S. Magura.

(Plates IV and V.)

Archaeological Problems of Northern Australia. D. S. Davidson. (Plates VIII-X.)

\section{Notes and Queries on Anthropology}

INVALUABLE TO ALI TRAVELLERS AND RESIDENTS AMONG PRIMITIVE RACES Fifth Edition, enlarged and thoroughly revised. Price 6 s.

\section{Huxley Memorial Lectures}

Complete List on application.

\section{Occasional Papers}

Complete List on application.

\section{Man}

A MONTHLY JOURNAL OF ANTHROPOLOGICAL SCIENCE.

Annual Subscription, $f_{\mathrm{I}}$; monthly numbers, 2s. net. 


\section{THE LONDON GOLDSMITHS I200-I800}

A Record of the Craftsmen, their Trade-Cards and Shop-signs By SIR AMBROSE HEAL

By the direction of THE WORSHIPFUL COMPANY OF GOLDSMITHS OF LONDON

A limited edition of 350 copies, with 80 collotype plates. £4 4s. net

\section{A HANDBOOK OF ENGLISH MEDIEVAL SCULPTURE} By ARTHUR GARDNER

49I illustrations. 15s. net

'A work as complete as archæological research can make it. The illustrations are admirable.' $\quad$ HERBERT READ in Time and Tide.

\section{BURGHARDUS DE BELLEVAUX APOLOGIA DE BARBIS}

A Twelfth Century Treatise on Beards and their Moral and Mystical Significance

Now, for the first time edited from the only known Manuscript, British Museum MS. add. 41997 By E. PH. GOLDSCHMIDT

With 2 collotype plates. Edition limited to 350 copies 17s. 6d. net

\section{STUDIES IN EARLY GELTIG NATURE POETRY By KENNETH JACKSON \\ 12s. 6d. net}

The first part contains translations of all the known poems, both Irish and Welsh; the second is a study of their literary history and comparative relations with other similar literatures, such as Anglo-Saxon and Medieval Latin.

GA M B R I G E U N I ER S ITY PRES S 